\title{
Invader-invader interactions in relation to environmental heterogeneity leads to zonation of two invasive amphipods, Dikerogammarus villosus (Sowinsky) and Gammarus tigrinus Sexton: amphipod pilot species project (AMPIS) report 6
}

\author{
Dirk Platvoet $\cdot$ Jaimie T. A. Dick • \\ Calum MacNeil · Mariëlle C. van Riel • \\ Gerard van der Velde
}

Received: 17 January 2008/ Accepted: 13 August 2008/Published online: 7 July 2009

(C) The Author(s) 2009. This article is published with open access at Springerlink.com

\begin{abstract}
As biological invasions continue, interactions occur not only between invaders and natives, but increasingly new invaders come into contact with previous invaders. Whilst this can lead to species replacements, co-existence may occur, but we lack knowledge of processes driving such patterns. Since environmental heterogeneity can determine species
\end{abstract}

D. Platvoet $(\bowtie)$

Zoological Museum Amsterdam, Institute for Biodiversity and Ecosystem Dynamics, University of Amsterdam, P.O. Box 94766, 1090 GT Amsterdam, The Netherlands e-mail: platvoet@science.uva.nl

J. T. A. Dick

School of Biological Sciences, Queen's University Belfast, Medical Biology Centre (MBC), 97 Lisburn Road, Belfast, Northern Ireland BT9 7BL, UK

C. MacNeil

The Government Laboratory, Department of Local Government and the Environment, Ballakermeen Road, Douglas, Isle of Man IM1 4BR, British Isles

M. C. van Riel · G. van der Velde

Department of Animal Ecology and Ecophysiology, Institute for Wetland and Water Research, Radboud University Nijmegen, Heyendaalseweg 135,

6525 AJ Nijmegen, The Netherlands

G. van der Velde

National Natural History Museum Naturalis, P.O. Box 9517, 2300 RA Leiden, The Netherlands richness and co-existence, the present study examines habitat use and its mediation of the predatory interaction between invasive aquatic amphipods, the Ponto-Caspian Dikerogammarus villosus and the N. American Gammarus tigrinus. In the Dutch Lake IJsselmeer, we found broad segregation of $D$. villosus and $G$. tigrinus by habitat type, the former predominating in the boulder zone and the latter in the soft sediment. However, the two species co-exist in the boulder zone, both on the short and longer terms. We used an experimental simulation of habitat heterogeneity and show that both species utilize crevices, different sized holes in a plastic grid, non-randomly. These amphipods appear to optimise the use of holes with respect to their 'C-shape' body size. When placed together, D. villosus adults preyed on G. tigrinus adults and juveniles, while G. tigrinus adults preyed on $D$. villosus juveniles. Juveniles were also predators and both species were cannibalistic. However, the impact on G. tigrinus of the superior intraguild predator, D. villosus, was significantly reduced where experimental grids were present as compared to absent. This mitigation of intraguild predation between the two species in complex habitats may explain the co-existence of these two invasive species.

Keywords Amphipod - Cannibalism . Co-existence - Dikerogammarus villosus . Gammarus tigrinus - Habitat heterogeneity . Predation 


\section{Introduction}

Contemporary biological invasions are major drivers of global biodiversity change (Ricciardi 2007). Invaders impact native species through competition, herbivory, predation, parasitism, vectoring of pathogens, hybridization, and through physical and chemical modifications of habitats (e.g. Mack et al. 2000; Manchester and Bullock 2000). The continuing anthropogenic movement of species is now resulting in new invaders coming into contact with previous invaders (e.g. Dick and Platvoet 2000; Ricciardi 2001; Lohrer and Whitlatch 2002). Such invaderinvader interactions may be positive as well as negative, with some support for 'invasional meltdown' due to facilitative interactions among invaders, often when the species are from the same donor region (Simberloff and Von Holle 1999; Ricciardi 2001; Simberloff 2006). There are examples of subsequent invaders replacing previous invaders (Van der Velde et al. 2000; Lohrer and Whitlatch 2002), for example, through intraguild predation (Dick and Platvoet 2000). However, we lack understanding of the processes whereby multiple invasive species may come to co-exist, in particular where they are strongly negatively interacting invaders from very different biogeographical realms. There is much literature on the relationship between environmental heterogeneity, species richness and co-existence with respect to communities of 'native' species (Kadmon and Allouche 2007). In the present study, we take such an approach to examine the role of habitat heterogeneity in the ecological relationship between two consecutive and strongly interacting invaders from very different donor regions.

Several non-indigenous amphipods have replaced native species in various regions of the world (Dick 1992; Dick and Platvoet 2000; Van der Velde et al. 2000, 2002; Van Overdijk et al. 2003; Jazdzewski et al. 2004; Meyer et al. 2004). The river Rhine is a heavily invaded system, particularly due to its connection to the river Danube catchment with the opening of the Main-Danube Canal in 1992. This has led to an increasing number of Ponto-Caspian species invading the Rhine drainage system (Bij de Vaate et al. 2002, 2006; Van der Velde et al. 2002). One of these, the amphipod Dikerogammarus villosus, is now widely distributed in western Europe (Dick and
Platvoet 2000; Devin et al. 2003; Josens et al. 2005; Bollache et al. 2008). This species is a strong intraguild predator that has replaced a number of native species, such as Gammarus duebeni (Dick and Platvoet 2000). However, D. villosus has come into contact with a previous invader in Europe, the N. American Gammarus tigrinus. Whilst this latter species also declined when $D$. villosus arrived, the two species appear able to co-exist at the local and regional scale (e.g. Dutch Lakes; Dick and Platvoet 2000). We therefore take a field and laboratory approach to elucidate the processes behind such patterns. First, we sample the shoreline of the Lake Gouwzee region of the Dutch Lake IJsselmeer and examine patterns of invader-invader co-occurrence with respect to habitat. Then, in the laboratory, we examine if individuals of both species utilise artificial substrate heterogeneity randomly or selectively. Finally, we examine experimentally the role of such habitat heterogeneity in mediating intraguild predation between these species and hence if this helps to explain their co-existence.

\section{Materials and methods}

Study site

Lake Gouwzee is part of the Markermeer/IJsselmeer complex of Dutch lakes (Fig. 1a). The borders of Lake Gouwzee are artificially protected from wave action by imported stone boulders (Fig. 1b, c). Before $D$. villosus entered the Gouwzee, the native $G$. duebeni and invasive G. tigrinus co-existed in the boulder zone, while G. tigrinus was also found in the soft sediments and zebra mussel (Dreissena polymorpha) beds on the bottom of the lake (Dick and Platvoet 2000).

Field study

In November 2003, we took 3-min kick samples with a handheld net (5 each of hard and soft substrate; see Fig. 1b, c) at each of four sites along a $400 \mathrm{~m}$ stretch of coastline. Ambient water temperature was $17^{\circ} \mathrm{C}$ and conductivity $850 \mu \mathrm{S} \mathrm{cm}{ }^{-1}$. Amphipods were sorted in the laboratory and identified to species. 
Fig. 1 Distribution and relative abundances of Dikerogammarus villosus and Gammarus tigrinus along a $400 \mathrm{~m}$ stretch of shore of Lake Gouwzee, the Netherlands. Percentages refer to G. tigrinus: a Map of the Netherlands with Lake Gouwzee indicated; b Picture of typical shoreline structure; c graphical representation of shoreline structure with dominant macroinvertebrates; $\mathbf{d}$ piediagrams of relative abundance of Dikerogammarus villosus (black) and Gammarus tigrinus (white) at five sites along the shore

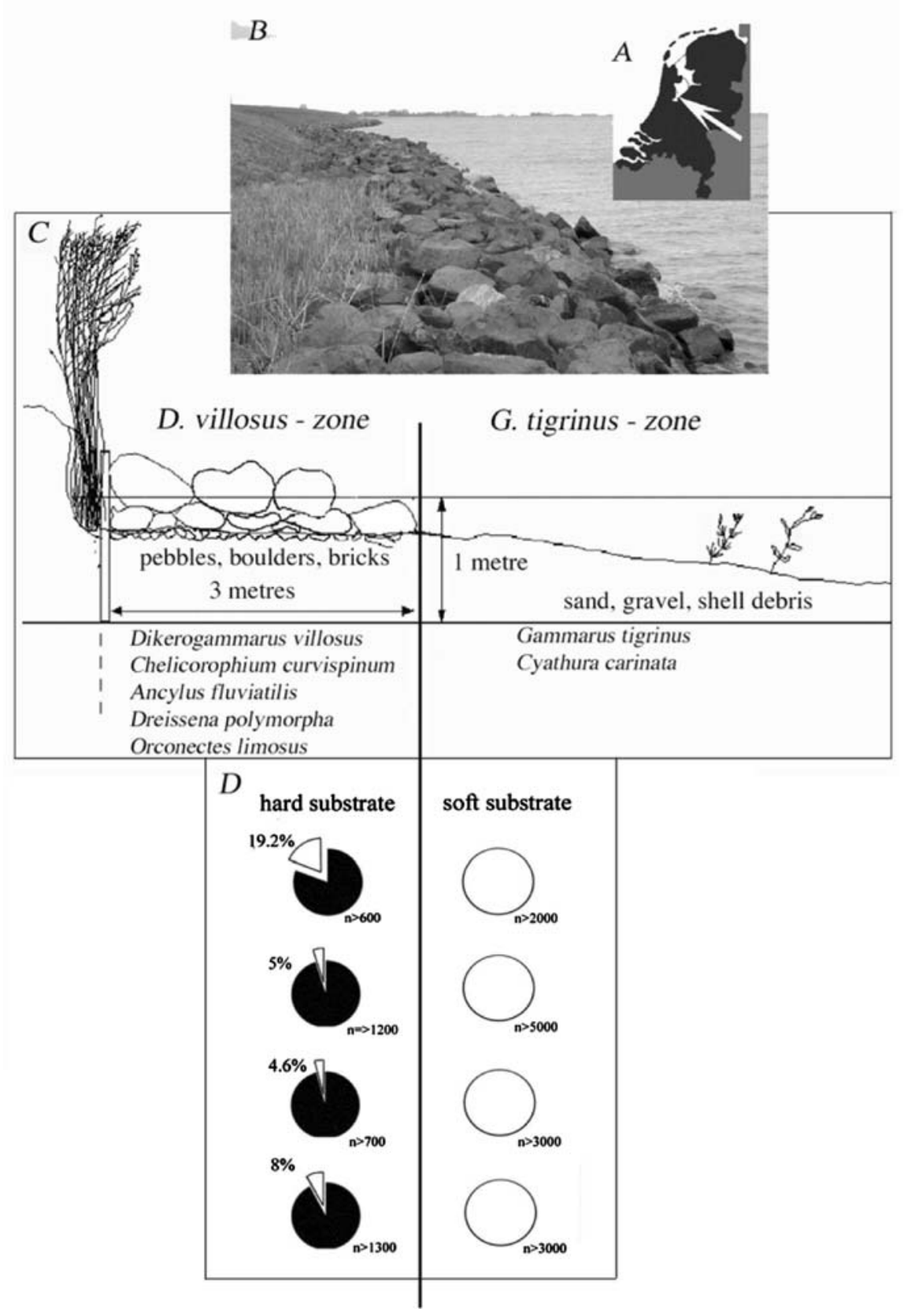

\section{Experiments}

Specimens of D. villosus and G. tigrinus for experiments were collected as above and maintained separately in large aerated aquaria in the laboratory at $19^{\circ} \mathrm{C}$ with flora and fauna from the Gouwzee and allowed 1 day to acclimate.
Plastic aquaria of $20 \times 20 \times 8 \mathrm{~cm}$ (length $\times$ width $\times$ height) were supplied with lake water and, on the bottom, a plexi-glass grid of $20 \times 20 \times 2 \mathrm{~cm}$ (length $\times$ width $\times$ height) with $81(9 \times 9)$ randomly distributed cylindrical holes of 7 different diameters: 3, 4, 5, 6, 7, 8 and $9 \mathrm{~mm}$ (Fig. 2). The diameter/depth ratio for all holes was 0.5 , thus the respective depth of 

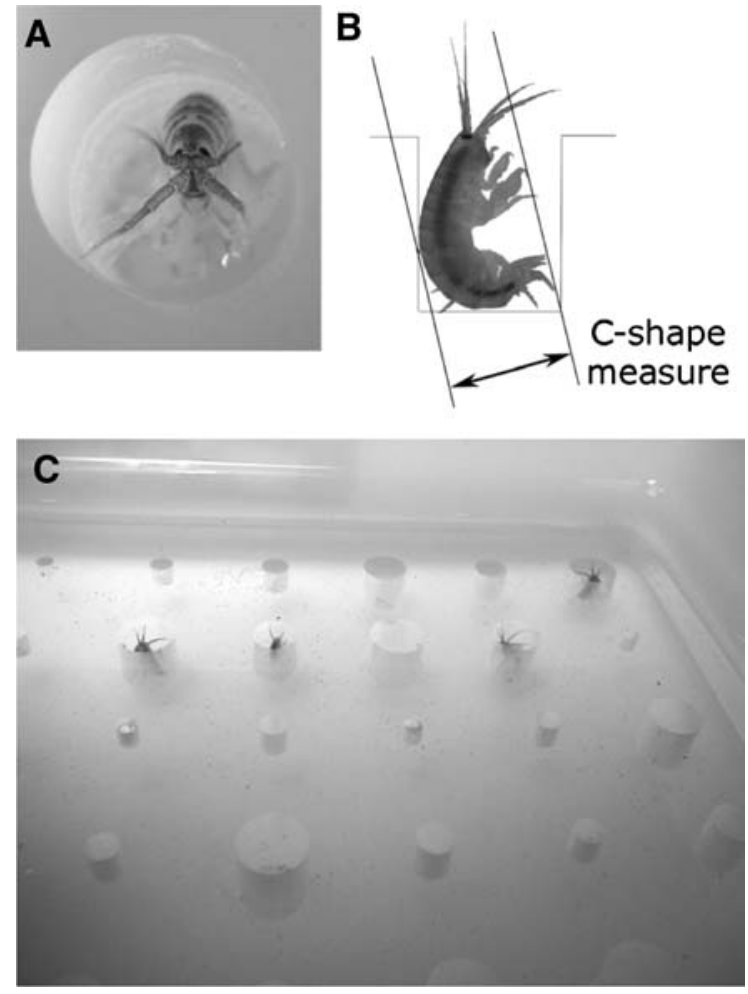

Fig. 2 a Dikerogammarus villosus in grid hole with each antenna covering a quadrant (frontal view); b Lateral view of D. villosus in grid hole (also indicating measurement of cshape; c The grid, showing four specimens of D. villosus in holes. Antennae extend out of the holes

the holes was $6,8,10,12,14,16$ and $18 \mathrm{~mm}$. This grid was designed to simulate habitat heterogeneity and allow assessment of random versus selective use of crevices and the influence of this on inter-species interactions. All experiments took place at a water temperature of $19^{\circ} \mathrm{C}$.

Dikerogammarus villosus were sorted into three size groups by body length, taken from the base of the antennae to the base of the telson: (1) $3-5 \mathrm{~mm}$;
(2) 8-12 mm; (3) 16-22 mm. Gammarus tigrinus were sorted into two size groupings: (1) $3-5 \mathrm{~mm}$; (2) 8-12 mm. For 10 specimens of each species in each group we measured, with digital calipers, maximum lateral width, maximum dorso-ventral height and maximum 'C-shape' (animals curled) (Table 1). From this, we determined that size group 1 animals of both species had access to all holes, size group 2 animals to 4-9 $\mathrm{mm}$ holes and size group 3 animals to 6-9 $\mathrm{mm}$ holes. We further confirmed this by placing 10 animals of each size group in separate tanks with grids that had their 'accessible' holes blocked-no animal took up residence in holes deemed inaccessible as above.

Experiment 1-Do amphipods optimize hole choice by size?

Separately for each of the three size groups of $D$. villosus and the two size groups of G. tigrinus, 10 animals were placed in each of four replicate grids and, $24 \mathrm{~h}$ later, we counted the numbers of animals in each hole size. Since the number of holes of accessible size in each tank exceeded the number of animals, we deemed each hole residency as an independent datum. A $\chi^{2}$ test was used to determine if hole size residency deviated significantly from random.

Experiment 2-Intraguild predation and cannibalism

Intraguild predation and cannibalism were tested, with and without the experimental grid, in three protocols: (1) adult D. villosus (size class 3) plus, separately, either adult G. tigrinus (size class 2), juvenile G. tigrinus or juvenile D. villosus; (2) adult G. tigrinus plus, separately, either juvenile G. tigrinus

Table 1 Size ranges of body width, body height and 'C-shape' in three size-groups of D. villosus and two size-groups of $G$. tigrinus

\begin{tabular}{llll}
\hline $\begin{array}{l}\text { Species/size groups } \\
\text { (body length) }\end{array}$ & $\begin{array}{l}\text { Range of lateral } \\
\text { widths (mm) }\end{array}$ & $\begin{array}{l}\text { Range of dorso-ventral } \\
\text { heights (mm) }\end{array}$ & $\begin{array}{l}\text { Range of C-shapes } \\
\text { (curled) (mm) }\end{array}$ \\
\hline D. villosus group 1: $3-5 \mathrm{~mm}$ & $0.3-0.5$ & $1.2-1.4$ & $2-2.4$ \\
G. tigrinus group 1: $3-5 \mathrm{~mm}$ & $0.2-0.4$ & $1.0-1.2$ & $1.8-2.4$ \\
D. villosus group 2: $8-12 \mathrm{~mm}$ & $0.5-1.2$ & $1.5-3$ & $2.5-3.4$ \\
G. tigrinus group 2: $8-12 \mathrm{~mm}$ & $0.4-0.9$ & $1.3-2.6$ & $2.1-3.2$ \\
D. villosus group 3: $16-22 \mathrm{~mm}$ & $3-3.2$ & $3.2-4$ & $6-7$ \\
\hline
\end{tabular}


or juvenile D. villosus; (3) juvenile D. villosus plus juvenile $G$. tigrinus. In each replicate of each of the 12 experimental groups, 10 of each species/size class were simultaneously introduced to the aquarium with $(n=5)$ and without $(n=5)$ experimental grids, and left for $16 \mathrm{~h}\left(8 \mathrm{~h}\right.$ light, $8 \mathrm{~h}$ dark) at $19^{\circ} \mathrm{C}$ and survivors counted. These data were converted to proportions and arcsine transformed for analyses (see Sokal and Rolph 1995), but Figures show raw percentages for clarity. We analysed the data by ANOVA using 'Statview'.

\section{Results}

Field study

Gammarus duebeni was completely absent from the shoreline. The hard substrate zone was dominated by D. villosus but with some G. tigrinus, whereas in the soft sediments of the lake bottom, only G. tigrinus was found in high numbers (Fig. 1d).

Experiment 1-Do amphipods optimize hole choice by size?

Both amphipod species rest in the holes with their antennae extended out of the hole (Fig. 2). D. villosus of all three size groups distributed themselves with respect to hole size in a non-random manner $\left(\chi_{6}^{2}=42.1\right.$, $P<0.001$, Fig. 3a; $\chi_{5}^{2}=40.21, P<0.001$, Fig. 3b; $\chi_{3}^{2}=12.6, P<0.01$, Fig. 3c). G. tigrinus showed a similar non-random use of holes $\left(\chi_{6}^{2}=54.6\right.$, $P<0.001$, Fig. 4a: $\chi_{5}^{2}=35.5, P<0.001$, Fig. 4 b). Clearly, individuals preferred to reside in hole diameters of around 1.5-2 times their 'C-shape' (Table 1) and indeed our observations suggest that animals position themselves within holes where they can take up this shape and touch the sides with their appendages.

Experiment 2-Intraguild predation and cannibalism

In the first protocol, where adult $D$. villosus were predators or cannibals, $99 \%$ of these adults survived. There was significantly higher overall survival of the other amphipods in the presence as compared to absence of grids $\left(F_{1,24}=177.8, P<0.001\right.$; Fig. 5a) and there was significantly lower survival of juveniles
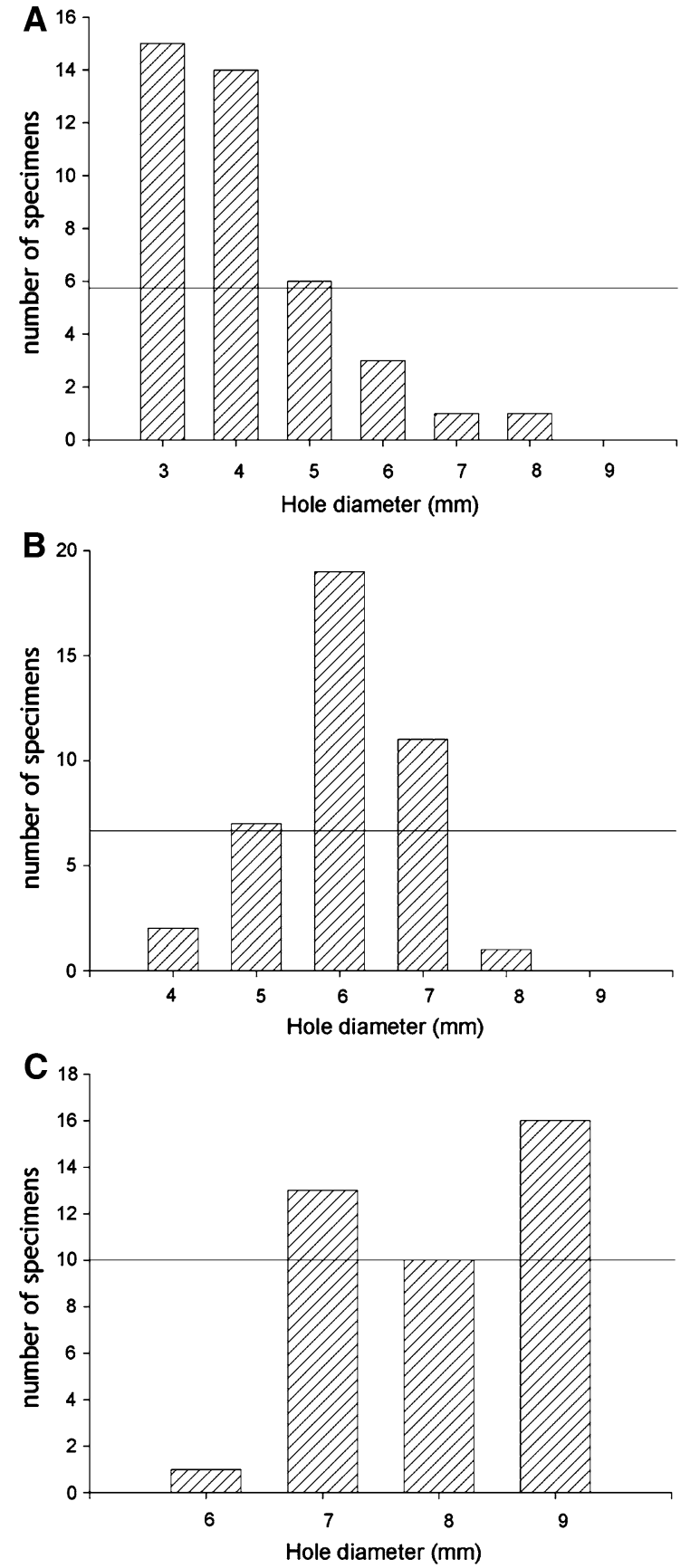

Fig. 3 Frequency distribution of Dikerogammarus villosus in the habitat grid, for size classes: a 3-5 mm; b $8-12 \mathrm{~mm}$; c 16-22 mm. Lines are expected frequencies of hole occupancy if animals distribute in holes at random

as compared to adults $\left(F_{2,24}=10.4, P<0.001\right.$; Fig. 5a), leading to a significant interaction effect $\left(F_{2,24}=4.2, \quad P<0.03\right.$; Fig. 5a). In the second 

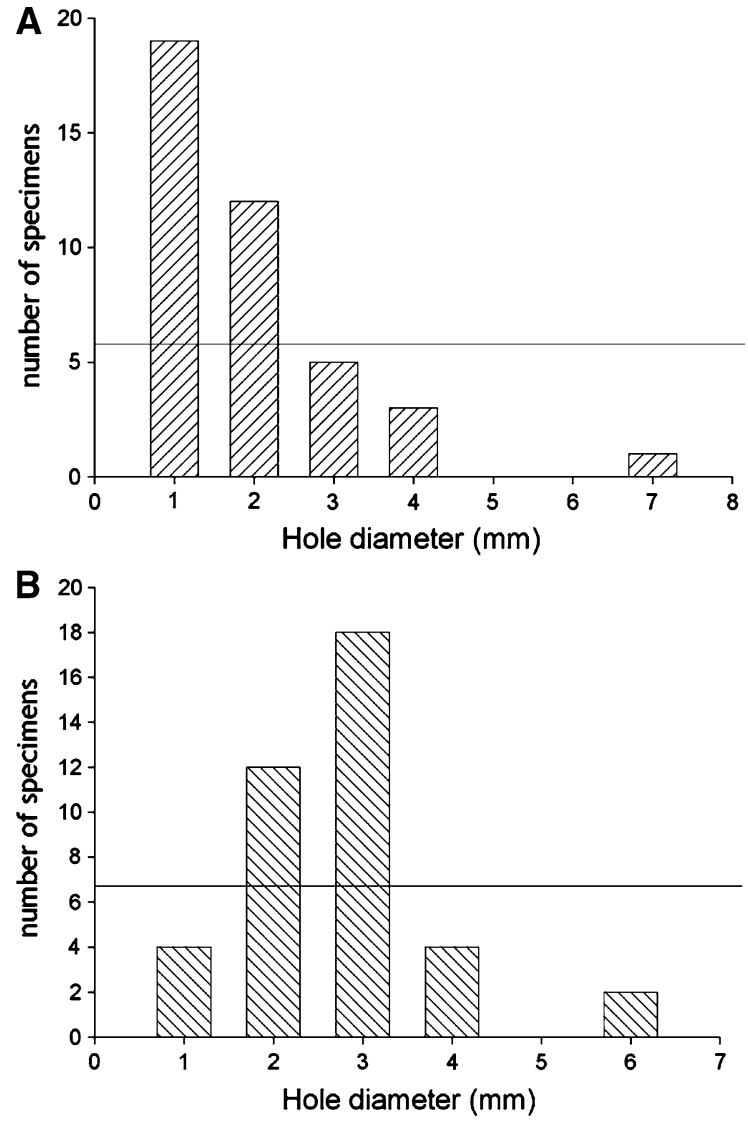

Fig. 4 Frequency distribution of Gammarus tigrinus in the habitat grid, for the size classes: a 3-5 mm and b $8-12 \mathrm{~mm}$. Lines are expected frequencies of hole occupancy if animals distribute in holes at random

protocol, where adult G. tigrinus were predators or cannibals, $96 \%$ of these adults survived. There was significantly higher overall survival of the other amphipods in the presence as compared to the absence of grids $\left(F_{1,16}=69.2, P<0.001\right.$; Fig. 5 b), with no significant overall difference in survival between juvenile $D$. villosus and juvenile $G$. tigrinus $\left(F_{1,16}=0.1\right.$, NS; Fig. $\left.5 b\right)$, but a significant interaction effect $\left(F_{1,16}=4.6, P<0.05\right.$; Fig. $\left.5 b\right)$, since some juvenile $D$. villosus, but no G. tigrinus, survived in the absence of grids. In the third protocol, where juveniles of the two species were predators and cannibals, there was a significantly higher survival of amphipods in the presence as compared to the absence of grids $\left(F_{1,8}=11.4, P<0.05\right.$, Fig. 5c) and significantly higher survival of $D$. villosus juveniles as compared to $G$. tigrinus juveniles $\left(F_{1,8}=11.7\right.$, $P<0.05$; Fig. 5c).
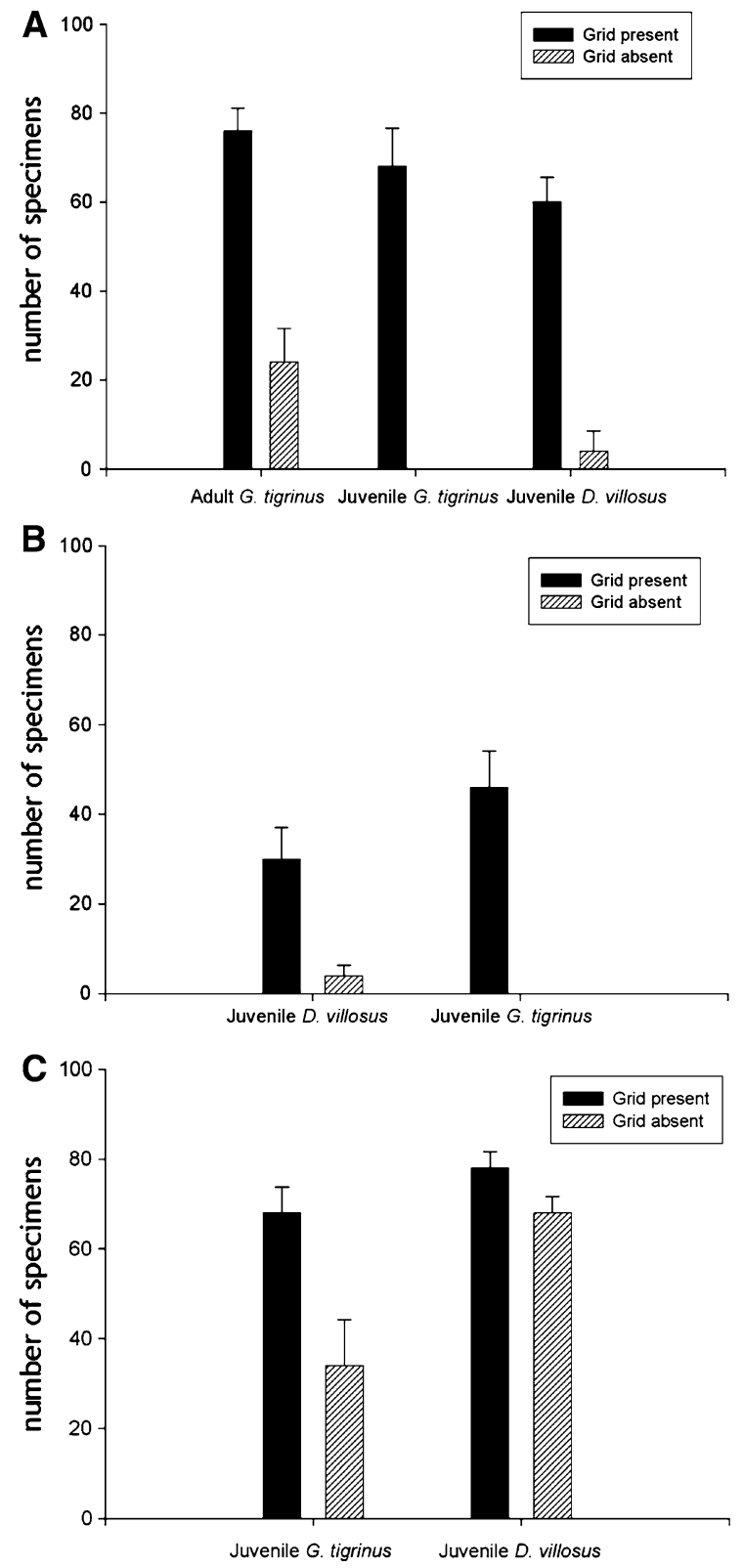

Fig. 5 Mean (+SE) survival of amphipods with and without experimental grids, in the presence of: a adult Dikerogammarus villosus; b adult Gammarus tigrinus; and $\mathbf{c}$ where all individuals were juveniles of the two species

\section{Discussion}

Availability of suitable habitat is important to potential prey animals, and is a limiting factor in their distribution (Pringle 1982; Hacker and Steneck 1990; Moksnes et al. 1998; Phelan et al. 2001; Nykänen and Huusko 2003; Kley and Maier 2005). 
Much research has focussed on the relationship between environmental heterogeneity and species richness and co-existence in un-invaded ecosystems (see Kadmon and Allouche 2007). Also, community structuring effects of invasive species are generally well understood (e.g. Zaret and Paine 1973; Vander Zanden et al. 1999; Kelly et al. 2006). Here, however, we examine the increasingly common scenario where two subsequent invasive species come into contact and co-exist and ask if environmental heterogeneity plays a role.

In 1998-1999, D. villosus invaded the Dutch Lake IJsselmeer and rapidly replaced the native $G$. duebe$n i$, with $G$. tigrinus distribution and abundance becoming much reduced (Dick and Platvoet 2000). Since then, G. duebeni has completely disappeared where D. villosus has colonised (Platvoet 2007), but G. tigrinus appeared, on the short term, to co-exist in the lake, albeit substantially reduced, with $D$. villosus (Dick and Platvoet 2000). Here the two invaders were found in broadly separate zones related to substrate structure (D. villosus boulders versus $G$. tigrinus sediment) in Lake Gouwzee, but with a degree of co-existence in the boulder zone that has persisted more long term (Dick and Platvoet 2000). D. villosus appears to choose stones and complex substrates (Van Riel et al. 2006) and avoid mud and sandy habitats, whereas G. tigrinus appears more catholic in its substrate choice (see also Dick 1996). Thus, G. tigrinus may escape interaction with D. villosus in some substrates, allowing the two species to persist at the local and regional scales as they are segregated by habitat. However, where the two species come into contact, they interact through intraguild predation (Dick and Platvoet 2000) and their continued co-existence in such habitats requires explanation.

In the laboratory, even in the absence of potential predators and cannibals, both D. villosus and G. tigrinus distributed themselves non-randomly with respect to artificial substrate heterogeneity. The smallest size class $(3-5 \mathrm{~mm})$ was found in the smallest holes in the experimental grid, with the medium size class $(8-12 \mathrm{~mm})$ preferring the holes best fitting their body size. The largest specimens $(16-22 \mathrm{~mm})$ were found in the three largest hole sizes of the grid, 7, 8 and $9 \mathrm{~mm}$. The animals appeared to select the hole that best accommodated the 'C-shape' of their curled bodies, with their appendages touching the surrounding surfaces. There may be many drivers of this habitat selection, including sheltering from water flow and wave actions, and avoiding predators such as fish, which may also have the effect of reducing the impact of intraguild predators. Thus, selection of crevices non-randomly may reduce interspecies interactions and contribute to co-existence.

Both D. villosus and G. tigrinus are cannibalistic and engage in inter- and intra-guild predation (MacNeil et al. 1997; Dick and Platvoet 2000; Dick et al. 2002). D. villosus, however, is a much stronger intraguild predator, capable of killing and consuming even inter-moult victims (Dick and Platvoet 2000). Clearly, however, the presence of heterogeneity supplied by our experimental grid significantly enhanced the survival of both adult and juvenile $G$. tigrinus in the face of $D$. villosus. Indeed, in the absence of the grid, all juvenile G. tigrinus disappeared, but with the grid around $70 \%$ survived. The grid also increased the survival of juvenile D. villosus, which are subject to cannibalism by adults. Adult G. tigrinus were predators of juvenile D. villosus and cannibals of juveniles, again the grid significantly reducing both interactions. Juveniles of both species also appeared to engage in intraguild predation and cannibalism, mitigated by habitat. Overall, these results indicate that complex environments offering a range of crevice sizes, such as boulder zones, may allow persistence of G. tigrinus adults and recruitment of juveniles even in the face of invasion by the superior intraguild predator, D. villosus. Also, G. tigrinus predation of D. villosus juveniles may further reduce the impact of the latter, and cannibalism as shown by both species may further aid their co-existence, as predicted theoretically (Dick et al. 1993).

There is a number of other factors that may contribute to the co-existence of these species in complex habitats such as Lake Gouwzee. Immigration by $G$. tigrinus from the soft sediment zone to the boulder zone may counter the predatory impact of D. villosus and this requires testing, perhaps with labelled or tagged individuals. Also, G. tigrinus has a high fecundity and short maturation time (Pinkster et al. 1977), but D. villosus is also highly fecund (Pöckl 2007). Interspecific competition may occur between these species and their co-existence mediated through niche differentiation (Kley and Meier 2005). However, intraguild predation among such species is 
such a direct and rapid process that competitive effects on fitness parameters such as growth and reproduction may be relatively unimportant (Polis et al. 1989; Dick et al. 1993; Dick and Platvoet 1996). Further, there may be parasite and/or predator mediation of interactions (Prenter et al. 2004; Palmer and Ricciardi 2005). Nevertheless, this study has indicated that a known and potent inter-specific interaction between these species is mediated by habitat use, but other mechanisms require assessment.

Studies of the interactions among invaders have generally to date focussed on competitive interactions and testing of the 'invasional meltdown' hypothesis, which posits a greater frequency of positive than negative interactions among invaders (Ricciardi 2007). Where invaders are strongly interactive and from different donor regions, and thus with no coevolutionary history, it may be expected that one species would completely dominate the other. Here, however, it is shown that a previous invader is coexisting, albeit at much reduced abundance, with a subsequent invader which is a superior intraguild predator (Dick and Platvoet 2000). This may be mediated by environmental heterogeneity, since a predisposition to the non-random use of refuges significantly reduced the negative effects of the inter-specific interaction. The present studied system is, however, heavily modified by man and may not be representative for invasions into pristine habitats. Nevertheless, we encourage studies of mechanisms of co-existence and species displacement in a range of habitats and taxa such that we are better able to predict the structure and function of the many communities that in future will be dominated by, or entirely composed of, invasive species.

\section{Acknowledgments This is CWE publication No. 432.}

Open Access This article is distributed under the terms of the Creative Commons Attribution Noncommercial License which permits any noncommercial use, distribution, and reproduction in any medium, provided the original author(s) and source are credited.

\section{References}

Bij de Vaate A, Jazdzewski K, Ketelaars HAM et al (2002) Geographical patterns in range extension of Ponto-Caspian macroinvertebrate species in Europe. Can J Fish Aquat Sci 59:1159-1174
Bij de Vaate A, Breukel R, Van der Velde G (2006) Long-term developments in ecological rehabilitation of the main distributaries in the Rhine delta: fish and macroinvertebrates. Hydrobiologia 565:229-242

Bollache L, Dick JTA, Farnsworth KD et al (2008) Comparison of the functional responses of invader and native amphipods. Biol Lett 4:166-169

Devin S, Piscart C, Beisel JN et al (2003) Ecological traits of the amphipod invader Dikerogammarus villosus on a mesohabitat scale. Arch Hydrobiol 158:43-56

Dick JTA (1992) The nature and implications of differential predation between Gammarus pulex and G. duebeni celticus (Crustacea: Amphipoda). J Zool Lond 227:171-183

Dick JA (1996) Post-invasion amphipod communities of Lough Neagh, N. Ireland; influences of habitat selection and differential predation. J Anim Ecol 65:756-767

Dick JTA, Platvoet D (1996) Intraguild predation and species exclusions in amphipods: the interaction of behaviour, physiology and environment. Freshw Biol 36:375-383

Dick JTA, Platvoet D (2000) Invading predatory crustacean Dikerogammarus villosus eliminates both native and exotic species. Proc Roy Soc Lond B 267:977-983

Dick JTA, Montgomery I, Elwood RW (1993) Replacement of the indigenous amphipod Gammarus duebeni celticus by the introduced $G$. pulex: differential cannibalism and mutual predation. J Anim Ecol 62:79-88

Dick JTA, Platvoet D, Kelly DW (2002) Predatory impact of the freshwater invader Dikerogammarus villosus (Crustacea: Amphipoda). Can J Fish Aquat Sci 59:1078-1084

Hacker SD, Steneck RS (1990) Habitat architecture and the abundance and body-size dependent habitat selection of a phytal amphipod. Ecology 71:2269-2285

Jazdzewski K, Konopacka A, Grabowski M (2004) Recent drastic changes in the gammaridean fauna (Crustacea, Amphipoda) of the Vistula River deltaic system in Poland caused by alien invaders. Divers Distrib 10:81-87

Josens G, Bij de Vaate A, Usseglio-Polatera P et al (2005) Native and exotic amphipoda and other peracarida in the River Meuse: new assemblages emerge from a fast changing fauna. Hydrobiologia 542:203-220

Kadmon R, Allouche O (2007) Integrating the effects of area, isolation, and habitat heterogeneity on species diversity: A unification of island biogeography and niche theory. Am Nat 170:443-454

Kelly DW, Bailey RJE, MacNeil C et al (2006) Invasion by the amphipod Gammarus pulex alters community composition of native freshwater macroinvertebrates. Divers Distrib 12:525-534

Kley A, Maier G (2005) An example of niche partitioning between Dikerogammarus villosus and other invasive and native gammarids: a field study. Limnology 64:85-88

Lohrer AM, Whitlatch RB (2002) Interactions among aliens: apparent replacement of one exotic species by another. Ecology 83:719-732

Mack RN, Simberloff D, Lonsdale WM et al (2000) Biotic invasions: causes, epidemiology, global consequences, and control. Ecol Appl 10:689-710

MacNeil C, Dick JTA, Elwood RW (1997) The trophic ecology of freshwater Gammarus (Crustacea: Amphipoda); problems and perspectives concerning the Functional Feeding Group concept. Biol Rev 72:349-364 
Manchester SJ, Bullock JM (2000) The impacts of non-native species on UK biodiversity and the effectiveness of control. J App Ecol 37:845-864

Meyer A, Kaschek N, Meyer EI (2004) The effect of low flow and stream drying on the distribution and relative abundance of the alien amphipod, Echinogammarus berilloni (Catta, 1878) in a karstic system (Westphalia, Germany). Crustaceana 77:909-922

Moksnes P-O, Pihl L, Van Montfrans J (1998) Predation on postlarvae and juveniles of the shore crab Carcinus maenas: importance of shelter, size and cannibalism. Mar Ecol Prog Ser 166:211-225

Nykänen M, Huusko A (2003) Size-related changes in habitat selection by larval grayling (Thymallus thymallus L.). Ecol Freshwat Fish 12:127-133

Palmer ME, Ricciardi A (2005) Community interactions affecting the relative abundances of native and invasive amphipods in the St. Lawrence River. Can J Fish Aquat Sci 62:1111-1118

Phelan BA, Manderson JP, Stoner AW et al (2001) Size-related shifts in the habitat associations of young-of-the-year winter flounder (Pseudopleuronectes americanus): field observations and laboratory experiments with sediments and prey. J Exp Mar Biol Ecol 257:297-315

Pinkster S, Smit H, Brandse-de Jong N (1977) The introduction of the alien amphipod Gammarus tigrinus Sexton, 1939, in the Netherlands and its competition with indigenous species. Crustaceana 4:91-105

Platvoet D (2007) Dikerogammarus villosus an amphipod with a bite. Thesis University of Amsterdam

Pöckl M (2007) Strategies of a successful new invader in European fresh waters: fecundity and reproductive potential of the Ponto-Caspian amphipod Dikerogammarus villosus in the Austrian Danube, compared with the indigenous Gammarus fossarum and G. roeseli. Freshw Biol 52:50-63

Polis G, Myers CA, Holt RD (1989) The ecology of intraguild predation: potential competitors that eat each other. Ann Rev Ecol Syst 20:297-330

Prenter J, MacNeil C, Dick JTA et al (2004) Roles of parasites in animal invasions. Trends Ecol Evol 19:385-390

Pringle S (1982) Factors affecting the microdistribution of different sizes of the amphipod Gammarus pulex. Oikos 38:369-373
Ricciardi A (2001) Facilitative interactions among aquatic invaders: is an "invasional meltdown" occurring in the Great Lakes? Can J Fish Aquat Sci 58:2513-2525

Ricciardi A (2007) Are modern biological invasions an unprecedented form of global change? Conserv Biol 21: 329-336

Simberloff D (2006) Invasional meltdown 6 years later: important phenomenon, unfortunate metaphor, or both? Ecol Lett 9:912-919

Simberloff D, Von Holle B (1999) Positive interactions of nonindigenous species: invasional meltdown? Biol Inv 1:21-32

Sokal R, Rolph FJ (1995) Biometry. WH Freeman, San Francisco, p 887

Van der Velde G, Rajagopal S, Kelleher B et al (2000) Ecological impact of crustacean invaders: general considerations and examples from the Rhine River. In: Von Vaupel Klein JC, Schram FR (eds), The biodiversity crisis and Crustacea. Proceedings of the Fourth International Crustacean Congress. Balkema Rotterdam, The Netherlands. Crustacean Issues 12:3-33

Van der Velde G, Nagelkerken I, Rajagopal S (2002) Invasions by alien species in inland freshwater bodies in western Europe: the Rhine delta. In: Leppäkoski E, Gollasch S, Olenin $\mathrm{S}$ et al (eds) Invasive aquatic species of Europe. Distribution impacts and management. Kluwer Scientific Publishers, Dordrecht, The Netherlands, pp 360-372

Van Overdijk CDA, Grigorovich IA, Mabee T et al (2003) Microhabitat selection by the amphipods Echinogammarus ischnus and Gammarus fasciatus in laboratory experiments and in Lake Erie. Freshw Biol 48:567-578

Van Riel MC, Van der Velde G, Rajagopal S et al (2006) Trophic relationship in the lower Rhine food web during invasion and after establishment of the Ponto-Caspian invader Dikerogammarus villosus. Hydrobiologia 565: 39-57

Vander Zanden MJ, Casselman JM, Rasmussen JB (1999) Stable isotope evidence for the food web consequences of species invasions in lakes. Nature 401:464-467

Zaret TM, Paine T (1973) Species introduction in a tropical lake. Science 182:449-455 